Vol. 5 (1996): 515-520.

\title{
A simple culture system for time-lapse video recording of bovine embryos
}

\author{
Jaana Peippo and Peter Bredbacka \\ Agricultural Research Centre of Finland, Institute of Animal Production, FIN-31600 Jokioinen, Finland, \\ e-mail: jaana.peippo@mtt.fi
}

\begin{abstract}
Continuous observation of embryonic growth can improve understanding of the early developmental events and allow us to use parametric statistical analyses with time as a parameter. A cinematographic study such as that reported here utilizes time-lapse video recording. Previously published methods for time-lapse video recording have involved building an incubator around a microscope, a process that is both expensive and laborious. Here we present a simplified method for time-lapse video recording of early bovine embryo development. The embryos were cultured during a 24 -hour period in a standard pregassed tissue culture bottle, which was darkened and placed on the heating stage of an inverted microscope for recording through a red filter. The control embryos were cultured in a conventional $\mathrm{CO}_{2}$ incubator. After 10 replicates we could not find a statistically significant difference between the cell numbers of these two treatments $(\mathrm{P}=0.95)$, suggesting that the culture setup is appropriate for continuous observation of early cleavage of the cattle embryo.
\end{abstract}

Key words: cinematography, mini embryo culture device, cattle, development

\section{Introduction}

Improvements in the in vitro production of embryos depend on well-designed embryo culture experiments. This is particularly important in domestic species, in which better culture conditions need to be defined. The traditional approach in performing embryo culture experiments includes an end point, say, 7 days after insemination. Typically the data from such experiments is expressed in categories, such as the propor- tion of blastocysts at the end of the culture. The choice of an appropriate end point can be a problem. For instance, two culture treatments may appear to be equally successful with a certain end point, although a different outcome might have been obtained with an earlier or later end point.

Continuous observation of embryo culture produces considerably more information than the end point approach. Abnormal events at the cleavage stages may not be recognized in embryos appearing as normal blastocysts after one 


\section{AGRICULTURAL AND FOOD SCIENCE IN FINLAND}

Peippo, J. \& Bredbacka, P. Time-lapse video recording of embryos

week of culture. The timing of early events can also be indicative of subsequent embryo viability (McKiernan and Bavister 1994). It has been demonstrated that bovine embryos reaching the 2-cell stage by 30 -h post insemination (hpi) are the ones most likely to continue development and to give the highest rate of compacted morulae, blastocysts and hatching (Plante and King 1992, Miller et al. 1992, Van Soom et al. 1992). Furthermore, continuous observation facilitates more versatile use of parametric statistical analyses, as time can be used as a parameter.

In practice, continuous monitoring of embryo development makes use of time-lapse video recording. Several authors have demonstrated the potential of this approach (Mulnard 1967, Massip and Mulnard 1980, Massip et al. 1982, 1983a and 1983b, Bavister 1988, Grisart et al. 1994, Gonzales et al. 1995). However, the setup has usually been based on a $\mathrm{CO}_{2}$ incubator built around a microscope. This easily becomes too expensive for many laboratories. We present here a simple and inexpensive culture system designed for time-lapse video recording of early bovine embryo development. We compare the final cell numbers at the end of 24-h culture between the time-lapse video recording and regular $\mathrm{CO}_{2}$ incubator environments.

\section{Material and methods}

\section{In vitro embryo production}

The oocytes were aspirated from ovaries of slaughtered cows and matured in TCM-199 supplemented with $5 \%$ foetal calf serum, $5 \%$ oestrous cow serum, $0.25 \mathrm{mM}$ sodium pyruvate, $2 \mathrm{mM}$ glutamine, $100 \mathrm{IU}$ penicillin/ml, $100 \mu \mathrm{g}$ strepto$\mathrm{mycin} / \mathrm{ml}, 2 \mu \mathrm{g} \mathrm{FSH} / \mathrm{ml}$ (USDA-oFSH-18), $10 \mu \mathrm{g}$ LH/ml (USDA-bLH-B-6) and $1 \mu \mathrm{g}$ estradiol-17 $/$ $\mathrm{ml}$ at $39^{\circ} \mathrm{C}$ in $5 \% \mathrm{CO}_{2}: 95 \%$ air. After $24 \mathrm{~h}$ of maturation, the oocytes were inseminated with $1.5 \times$ $10^{6}$ spermatozoa/ml in fert-TALP medium (Parrish et al. 1988) for $20 \mathrm{~h}$ at $39^{\circ} \mathrm{C}$ in $5 \% \mathrm{CO}_{2}: 95 \%$ air.

\section{In vitro embryo culture}

After 20-h fertilization, the cumulus cells were removed by vortexing for $90 \mathrm{~s}$, and about 12 presumptive zygotes were placed in each 1-3 $\mu \mathrm{l}$ drop of preincubated culture medium. The culture medium was CR1 (Rosenkrans and First 1991) supplemented with $5.56 \mathrm{mM}$ of glucose and covered with mineral oil either in a $100-\mathrm{ml}$ tissue culture flask (Nunc) or 4-well culture dish (Nunc). The culture flask was darkened with black PVC tape at the top and on the sides leaving only a small window at the top for microscope observation (Fig. 1). After $2 \mathrm{~h}$ of equilibration at $39^{\circ} \mathrm{C}$ in $5 \% \mathrm{CO}_{2}: 95 \%$ air in an incubator, the culture flask was closed and placed on the heating stage (Linkam) of an inverted microscope; the control zygotes were placed in a 4-well culture dish and kept in the incubator. Using red light $(>620 \mathrm{~nm}$ ) illumination caused by a filter placed over the window at the top of the flask, we recorded the culture period at $10 \mathrm{x}$ magnification with a Hamamatsu C4200 CCD microscope camera and a time-lapse video recorder (Fig. 2).

At 44 hpi both embryo cultures were terminated and the cleavage rates and the cell numbers per cleaved embryo were calculated in both groups.

\section{Statistical analysis}

The data (i.e. the average cell number per cleaved embryo) was analysed using Student's ttest following square-root transformation after combining the data on all the replicates in both treatments.

\section{Results}

Ten replicates were completed and analysed. There was no statistically significant difference between the replicates in cell numbers 


\section{AGRICULTURAL AND FOOD SCIENCE IN FINLAND}

Vol. 5 (1996): 515-520.

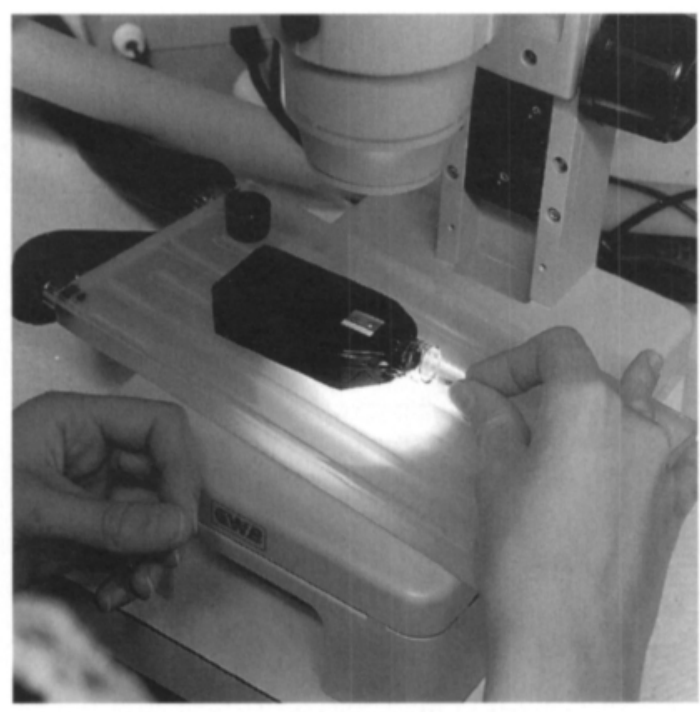

Fig. 1. For the video recording a standard tissue culture bottle (Nunc) was darkened at the top and on the sides leaving only a small window covered with a red filter at the top. (Photo: Jaana Peippo).

$(P=0.1350)$, thus the data on both treatments were combined for further analyses. A total of 120 zygotes were cultured in a culture flask (time-lapse) and 113 in a 4-well dish (incubator). During the culture, $94(78.3 \%)$ zygotes cleaved in the culture flask and $80(70.8 \%)$ in the 4-well culture dish. We could not find a statistically significant difference in the final cell numbers 44 hpi (Table 1) between these two treatments $(\mathrm{P}=0.95)$.

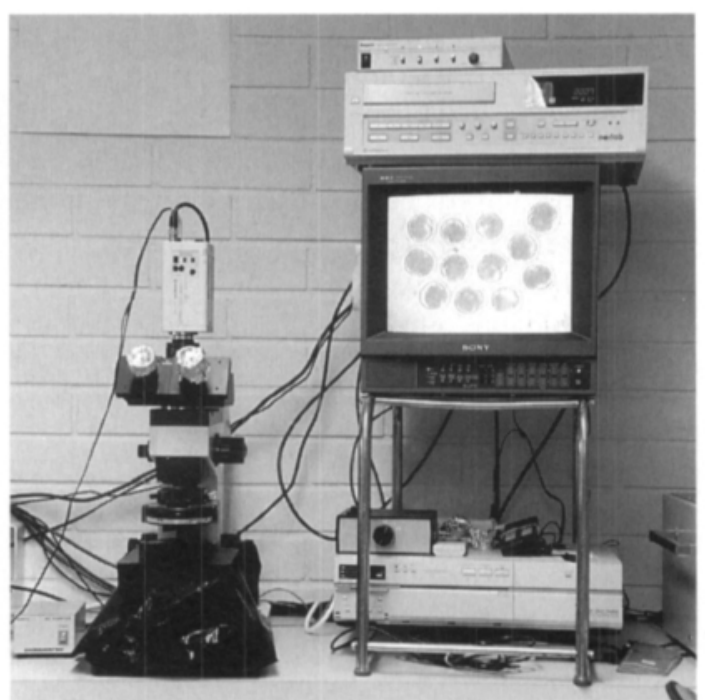

Fig. 2. The setup used for time-lapse video recording of bovine embryo development. (Photo: Jaana Peippo).

\section{Discussion}

The time-lapse culture system presented in our study is convenient and comparable to culture in the traditional $\mathrm{CO}_{2}$ incubator, at least when a 24-h culture period is used. This period covers three, sometimes four, cell cycles if it begins when the embryos are at the late 1-cell stage ( 20 hpi). In an ongoing study we transferred the

Table 1. Cleavage stage and mean values $( \pm$ SEM) of square-root transformed cell numbers after $24 \mathrm{~h}$ of culture in a time-lapse video recording enviroment and a standard $\mathrm{CO}_{2}$ incubator.

\begin{tabular}{lcccccc}
\hline Position & $\mathrm{N}$ & \multicolumn{5}{c}{ Number of cells/embryo } \\
& & 2 & $3-4$ & $5-7$ & $\geq 8$ & $\begin{array}{c}\text { Mean }( \pm \text { SEM) } \\
\text { cell no. }\end{array}$ \\
\hline $\begin{array}{l}\text { time-lapse } \\
\text { enviroment }\end{array}$ & 94 & 20 & 46 & 22 & 6 & $1.99 \pm 0.04$ \\
$\begin{array}{l}\mathrm{CO}_{2} \\
\text { incubator }\end{array}$ & 80 & 20 & 34 & 18 & 8 & $1.99 \pm 0.05$ \\
\hline
\end{tabular}

* Square root transformed cell data. 


\section{AGRICULTURAL AND FOOD SCIENCE IN FINLAND}

\section{Peippo, J. \& Bredbacka, P. Time-lapse video recording of embryos}

embryos to the incubator after 24-h culture in the time-lapse environment. The rate of development to compacted morulae or blastocysts is at currently $24 \%(\mathrm{n}=140)$, which is similar to that of control embryos cultured continuously in the incubator $(26 \%, \mathrm{n}=137)$.

In vitro culture exposes oocytes and embryos to visible daylight during handling in the laboratory (320-740 nm, 1600 lx) (Schumacher and Fisher 1988) and to the more intensive light of the microscope (14 $000 \mathrm{~lx}$ ) (Nakayama et al. 1994). We are not aware of any studies reporting the detrimental effects of light on bovine embryo development. In rabbit, daylight has been observed to have severe detrimental effects, especially at the 2-cell stage by causing cell degeneration and cell death (Schumacher and Fisher 1988). The effect of short split-dose exposures (e.g. $4 \times 1$ h) to visible light did not differ statistically from that of a single long exposure $(4 \mathrm{~h})$. In hamster and mouse, it has been suggested that the harmful effect of visible light is caused by an increase in hydrogen peroxide in the embryos, the response being slower in mouse than in hamster embryos, but reaching the same level after 3 min exposure (Nakayama et al. 1994). In hamster embryos the response also depended on the $\mathrm{O}_{2}$ concentration and the culture medium used. In a $20 \% \mathrm{O}_{2}$ atmosphere the increase of hydrogen peroxide levels occured earlier than in $5 \% \mathrm{O}_{2}$.

In our study bovine embryos were subjected to $22 \mathrm{~h}$ of continuous light from the microscope through a red filter $(>620 \mathrm{~nm})$. These long wavelengths have been observed to be less harmful for embryonic cells in rabbit than 300-500 -nm wavelengths (Daniel 1964). Red filters were also used by Bavister (1988) and Gonzales et al. (1995) in their time-lapse recordings. Another way to minimize the detrimental effect of visible light was introduced by Grisart et al. (1994), who switched the microscope light on for only a few seconds before a single frame was exposed (every minute) and switched it off immediately after. Observations made by Schumacher and Fisher (1988) do not, however, indicate that this latter approach is any less harmful for embryon- ic development than other approaches. Jacques et al. (1987) showed that a small but significant proportion of the light spectrum of $>500 \mathrm{~nm}$ penetrates the uterine lumen of rats and guinea pigs transabdominally, and they suggest that this light may have direct and/or indirect beneficial effects on foetal development. The role of light in cattle embryo development is, however, questionable as the reproductive tract of the cow is highly unlikely to be exposed to light this way due to the thickness of the skin.

Another enviromental factor to be considered when embryos are cultured in vitro is temperature. One way to solve the problem of temperature variations is to keep the room and table surfaces where embryos are handled constantly at over $30^{\circ} \mathrm{C}$ (Xu et al. 1987, 1992). In time-lapse studies temperature has been controlled by using either heated and humified gas (Bavister 1988, Gonzales et al. 1995) or a standard hairdryer to warm the culture enviroment (Grisart et al. 1994). In our study heating was carried out with a heating stage. The upper surface of the culture bottle was cooler than the surface against the heating stage, but the temperature of the heating stage was adjusted so that a thermometer placed inside the culture drop at the opening of the heating stage showed $39^{\circ} \mathrm{C}$.

The gas atmosphere in our study was maintained with a tightly closed conventional tissue culture bottle. According to Bavister (1988), it is important to have a constant gas flow as embryo metabolism can change the gas atmosphere in closed systems during prolonged culture. Our bottle was pregassed for $2 \mathrm{~h}$ before the addition of zygotes; at the end of the 24-h culture preservation of the gas atmosphere was checked with an indicator drop made of TCM-199 medium and placed next to the culture drop under the oil. This control on $\mathrm{pH}$ was made to establish whether any major $\mathrm{pH}$ changes were caused by leakage of $\mathrm{CO}_{2}$ from the culture atmosphere. At least in our short-term culture the lack of constant gas flow did not seem to disturb embryo development. In long-term cultures, the culture bottles could be regassed daily to avoid the problems associated with a change in gas atmosphere. 
Vol. 5 (1996): 515-520.

Our culture drops were smaller than those conventionally used, since we did not want embryos to change their positions. The small size of the culture drops may cause problems. For instance, accumulation of ammonium due to degradation of amino acids in culture medium can compromise embryonic development (Gardner and Lane 1993). Evaporation is another potential problem of culturing embryos in small microdrops. We noticed that the drop becomes smaller with long-term culture; water may be absorbed by the oil even if the oil is equilibrated with $0.9 \%$ $\mathrm{NaCl}$. In the method discussed here the upper surface of the culture bottle is colder than the bottom, thus facilitating evaporation of $\mathrm{H}_{2} \mathrm{O}$ from the oil and/or culture medium by condensation. This problem may be overcome by adding drops of medium to the flask. As the diameter of the opening in the middle of the microscope stage is $15 \mathrm{~mm}$, the temperature of the stage is set at about $44^{\circ} \mathrm{C}$ to achieve a temperature of $39^{\circ} \mathrm{C}$ in the drop containing the embryos. The additional drops, which are in closer contact with the heating stage, will then evaporate more readily and humidify the atmosphere of the culture flask, perhaps enough to prevent harmful evaporation of the drop containing the embryos. Another solution is to use larger drops and prevent the embryos from moving by placing them in small microwells produced at the bottom of the dish.

In conclusion, we find the culture system outlined above convenient and suitable for the short-term time-lapse video recording of cattle embryos. Our intention is to evaluate the feasibility of this system for long-term (7-day) culture, with modifications, if necessary.

Acknowledgements. The authors thank K. Bredbacka, T. Hytti and T.-M. Nieminen for technical assistance. FSH and LH were kindly provided by D.J. Bolt (USDA Animal Hormone Program, Beltsville, MD).

\section{References}

Bavister, B.D. 1988. A minichamber device for maintaining a constant carbon dioxide in air atmosphere during prolonged culture of cells on the stage of an inverted microscope. In Vitro Cellular \& Developmental Biology 24: 759-763.

Daniel, J.C., Jr. 1964. Cleavage of mammalian ova inhibited by visible light. Nature 201: 316-317.

Gardner, D.K. \& Lane, M. 1993. Amino acids and ammonium regulate mouse embryo development in culture. Biology of Reproduction 48: 377-385.

Gonzales, D.S., Pinheiro, J.C. \& Bavister, B.D. 1995. Prediction of the developmental potential of hamster embryos in vitro by precise timing of the third cell cycle. Journal of Reproduction and Fertility 105: 1-8.

Grisart, B., Massip, A. \& Dessy, F. 1994. Cinematographic analysis of bovine embryo development in serum-free oviduct- conditioned medium. Journal of Reproduction and Fertility 101: 257-264.

Jacques, S.L., Weaver, D.R. \& Reppert, S.M. 1987. Penetration of light into the uterus of pregnant mammals. Photochemistry and Photobiology 45: 637-641.

Massip, A. \& Mulnard, J. 1980.Time-lapse cinematographic analysis of hatching of normal and frozen-thawed cow blastocysts. Journal of Reproduction and Fertility 58: 457-478.

-, Mulnard , J., Van der Zwalmen, P., Hanzen, C. \& Ectors, F. 1982. The behaviour of cow blastocyst in vit- ro: cinematographic and morphometric analysis. Journal of Anatomy 134: 399-405.

-, Van der Zwalmen, P. \& Zwijsen, W. 1983a. Atypical hatching of a cow blastocyst leading to separation of complete twin half blastocysts. Veterinary Record 112: 301.

-, Zwijsen, W. \& Mulnard, J. 1983b. Cinematographic analysis of the cleavage of the cow egg from 2-cell to 16-cell stage. Archives de Biologie (Bruxelles) 94: 99106.

McKiernan, S.M. \& Bavister, B.D. 1994. Timing of development is a critical parameter for predicting successful embryogenesis. Human Reproduction 9: 2123-2129. Miller, G.F., Gliedt, D.L., Lester, T.D., Pierson, J.N., Rakes, J.M. \& Rorie, R.W. 1992. Addition of bovine oviductal epithelial cells (BOEC) and/or penicillamine, hypotaurine and epinephrine (PHE) to bovine in vitro fertilization (IVF) medium increases the subsequent embryo cleavage rate. Theriogenology 37: 259. (Abstract).

Mulnard, J.G. 1967. Analyse microcinématographique du développement de l'œuf de souris du stade II au blastocyte. Archives de Biologie, Liège 78: 107-138.

Nakayama, T., Noda, Y., Goto, Y. \& Mori, T. 1994. Effects of visible light and other environmental factors on the production of oxygen radicals by hamster embryos. Theriogenology 41: 499-510.

Parrish, J.J., Susko-Parrish, J., Winer, M.A. \& First, 


\title{
AGRICULTURAL AND FOOD SCIENCE IN FINLAND
}

Peippo, J. \& Bredbacka, P. Time-lapse video recording of embryos

N.L. 1988. Capacitation of bovine sperm by heparin. Biology of Reproduction 38: 1171-1180.

Plante, L. \& King, W.A. 1992. Effect of time to first cleavage on hatching rate of bovine embryos in vitro. Theriogenology 37: 274. (Abstract).

Rosenkrans, C.F., Jr. \& First, N.L. 1991. Culture of bovine zygotes to the blastocyst stage: Effect of amino acids and vitamins. Theriogenology 35: 266. (Abstract).

Schumacher, A. \& Fischer, B. 1988. Influence of visible light and room temperature on cell proliferation in preimplantation rabbit embryos. Journal of Reproduction and Fertility 84: 197-204.

Van Soom, A., Van Vlaenderen, I., Mahmoudzadeh,
A.R., Deluyker, H. \& de Kruif, A. 1992. Compaction rate of in vitro fertilized bovine embryos related to the interval from insemination to first cleavage. Theriogenology 38: 905-919.

Xu, K.P., Greve, T., Callesen, H. \& Hyttel, P. 1987. Pregnancy resulting from cattle oocytes matured and fertilized in vitro. Journal of Reproduction and Fertility 81: 501504.

-, Yadav, B.R., Rorie, R.W., Plante, L., Betteridge, K.J. \& King, W.A. 1992. Development and viability of bovine embryos derived from oocytes matured and fertilized in vitro and co-cultured with bovine oviductal epithelial cells. Journal of Reproduction and Fertility 94: 33-43.

\section{SELOSTUS}

\section{Yksinkertainen viljelymenetelmä naudan alkioiden aikaviivenauhoitusta varten}

\author{
Jaana Peippo ja Peter Bredbacka \\ Maatalouden tutkimuskeskus
}

\begin{abstract}
Aikaviivenauhoituksen avulla naudan alkionviljelyä voidaan seurata yhtäjaksoisesti optimiolosuhteissa, joissa lämpötila ja kaasukehä pysyvät vakioina ja alkiot eivät altistu valon lyhyille aallonpituuksille. Mikroskoopin ympärille on yleensä rakennettu pieni viljelykaappi, minkä takia menetelmä on ollut kallis ja työläs. Tässä kokeessa alkioita viljeltiin tavallisessa soluviljelypullossa, joka peitettiin mustalla teipillä pientä päällä olevaa ikkunaa lukuunottamatta. Pullon sisään luotiin kaasukehä siten, että pulloa pidettiin viljelykaapissa kaksi tuntia sekä ennen alkioiden pulloon siirtämistä että siirtämisen jälkeen. Pullo suljettiin tiukasti ja viljely aikaviivenauhoitettiin ikkunan päälle asetetun punaisen suodattimen läpi. Vil-
\end{abstract}

jelypullo asetettiin käänteismikroskoopin alle lämpölevylle, jonka lämpötila oli esikokeissa säädetty siten, että viljelypisaran lämpötila oli $39^{\circ} \mathrm{C}$. Kokeessa tehtiin 10 toistoa. Niissä verrattiin aikaviivenauhoitettujen ja samanaikaisesti viljelykaapissa kasvaneiden kontrollialkioiden solulukumääriä 24 tunnin viljelyn jälkeen. Tulokset analysoitiin T-testillä yhdistämällä toistojen aineistot neliöjuurimuunnoksen jälkeen. Aikaviivenauhoitettujen ja inkubaattorissa kasvaneiden alkioiden välillä ei ollut eroa $24 \mathrm{~h}$ viljelyn jälkeen $(\mathrm{p}=0.95)$, joten kehittämämme menetelmä soveltuu ilmeisesti hyvin naudan alkioiden varhaisvaiheiden seurantaan. 